\title{
Heidegger Felsefesinde Zamansallığın Göstereni Olarak Sıkıntı Kavramı ${ }^{1}$
}

\section{Emrah Günok}

Özet: Varlk ve Zaman boyunca Heidegger'in ana hedeflerinden biri de, içinde varlığın açımlandığı ufuk olan zamanın insanın özüne ait olduğunu göstermeye çalışmak olmuştur. Filozofun baş yapitından iki yıl sonra yayınlanan Metafiziğin Temel Kavramları başlıklı metinde ise bu ana izlek, sıkıntı ve dünya kavramlarının tartışılması üzerinden devam ettirilir. Bu yazının ana temasını meydana getirecek olan derin sıkıntı mefhumu, Varlık ve Zaman'da öne çıkan kaygı fenomeninin muadili olarak tasavvur edilebilir. Özü varoluşundan ibaret varolan olarak Dasein, sabit bir ontolojik zeminden yoksun oluşuna sıkıntı duyarak yanıt verir. Nesnesinin giderek belirsizleşmesi ölçüsünde derinlik kazandığı söylenebilecek üç tip sıkıntıdan bahsedilebilir. Söz konusu sıkıntı tiplerinin incelenmesi, dünyanın Dasein’a belli bir haletiruhiye üzerinden topyekûn verililiğine atıf yapan bulunuş kavramsallaştırmasını daha iyi kavramamıza olanak sağlayacaktır. Günümüz insanın temel haletiruhiyesi ise sıkıntı karşısında duyulan sıkıntı olarak tarif edilebilir. Kendi varlığının derin hakikatini açı̆̆a vurma potansiyeli taşıyan sıkıntıyı psikolojik bir rahatsızlık derekesine indirgeyip tedavi etmeye çalışmak, insanın kendi kendisinden kaçmaya ne denli yatkın olduğunun en iyi göstergelerinden biridir.

Anahtar Sözcükler: Dasein, derin sıkıntı, bulunuş, haletiruhiye, zaman

\begin{abstract}
One of the main targets of Heidegger throughout Being and Time is to try to make manifest the fact that time, which is the horizon in which being reveals itself, belongs to the very essence of human beings. In Fundamental Concepts of Metaphysics, which was published in the following two years after the publication of his magnum opus, this same theme is retained by means of the examination concerning the concepts of boredom and world. The notion of deep boredom, which will be the main theme of this paper, can be thought of as the equivalent of the phenomenon of anxiety that comes forward in Being and Time. Dasein, whose essence is its existence, responds its lack of an ontological ground by means of boredom. Three types of boredom can be considered, which can hierarchicly be put in order according to their depths; which, in its turn, increases as the object

Günok, Emrah. (2016). Heidegger Felsefesinde Zamansallığın Göstereni Olarak Sıkıntı Kavramı. Kilikya Felsefe Dergisi 2. ss. 16-38.

${ }^{1} 26$ Mart 2014 tarihinde, Prof. Dr. Hasan Ünal Nalbantoğlu'nu anmak amaciyla her yıl gerçekleştirilen sempozyumların “Kent, Mekan, Politika" başlıklı üçüncü ayağında aynı adla sunulmuş metnin gözden geçirilip geliştirmiş halidir.
\end{abstract}


becomes more and more obscure. An examination of these three provides us with a clearer understanding of the conception of attunement, which refers to the total givenness of the world to Dasein by means of a mood. The basic mood of the contemporary man can be conceived as boredom in the face of deep boredom. Relegating deep boredom, which is apt to make manifest the deep ontological truth of his being, to the level of a psychological desease, man proves himself to be the being who is prone to evade in the face of himself.

Keywords: Dasein, deep boredom, attunement, mood, time

\section{Giriş: Varlık Sorusundan Dasein'a}

Yaklaşık 2500 yıllık felsefe tarihinde Heidegger' in arayıp da bulamadı̆̆ı; eksikliğinden ötürü neredeyse yeni bir dil üretmeye mecbur kaldığı felsefî sezgi, varlık sorusunun [Seinsfrage] uygun bir biçimde sorulabilmesini sağlayacak bakış açısının olanağına yönelik sezgiden başkası değildir. En genel kavram olarak düşünülmüş olmasından ötürü kendiliğinden anlaşılabilirlik payesine layık görülmüş olan varlık [Sein], tam da bu sebeple unutuluşa terk edilmiştir (Heidegger, 2008, ss. 2-3). "Varlık nedir?" sorusunun dile getirildiği her durumda "-dir" koşacinın [copula] belli bir anlamda kullanılmak durumunda olması, sorulan şeyin zaten ve hâl-i hazırda biliniyor olduğu gerçeğini vurgulayacaktır. Şu halde bahsini etmekte olduğumuz sezginin varlığa ilişkin bir yanıttan ziyade, onun uygun bir biçimde sorgulanmasının önünü açan bir bakış açısına gebe olduğunu vurgulamak gerekecektir. Heidegger bu hususu “...varlık sorusunu yeniden sormak demek, öncelikle sorunun formülasyonunu yeterli ölçüde tanzim etmek anlamına gelecektir", sözleriyle ifade etmiştir (Heidegger, 2008, s. 4).

Varolanların varlığı sorusu doğa filozoflarından beri yanıtlanmaya çalışılmış, fakat varlık varolanlar içinde ayrıcalıklı da olsa bir varolan olmaktan hiçbir zaman kurtarılamamıştır. Günümüze kadar ulaşmayı başarmış olan bu "ortalama varlık anlayışı" mevcudiyeti [presence] varlığın yegâne anlamı olarak sabitlediğinden varlık incelemesi ontolojik olmaktan ziyade ontik bir karaktere büründürülmüş, yani empirik bir inceleme düzeyinde kalmıştır. Bunun sonuçlarından biri de, varlığa içinde açılacağ anlam ufkunu kazandıran zamanın mevcut varolanlardan biri olarak görülmeye başlanmasıdır. Varlık ve zaman arasındaki ontolojik ilişkiyi [T1] açımlama imkânı bu şekilde ortadan kalkmıştır [T2]. İncelemenin Kantçı anlamda aşkınsal [transcendental], Heideggerci anlamda ontolojik bir mahiyet kazanabilmesinin önkoşulu, varlığı mevcudiyet terimleri 
üzerinden düşünmeye bir son vermek; bilâkis, mevcudiyeti, kendine özgü zamansallığı içinde varlığın anlamlarından biri olarak kavramaktır. Bir şeyin mevcut olduğunu iddia ettiğimizde onun orada, algımıza verili oluşundan başka bir şey ifade etmediğimizegöre, Heidegger'in mevcudiyet ile nesne-lik ya da nesne-olma'yı kastediyor olduğu ortadadır. Şu halde fenomenolojinin, varlık ve zaman arasındaki ilişkiyi de göz önüne alarak, varlığı konu etmenin (algıya verililik anlamında nesneleştirmeden) başka bir yolunu bulması gerekeceği açıtır. ${ }^{2}$

Erken döneminde Heidegger bunu başarabilmek için varolanların Varlığını soranın kim olduğunu sorgulayarak işe başlar ve bu soruyu da insan varoluşunu karşılamak üzere özel olarak kullanıma soktuğu Dasein kavramı üzerinden yanıtlar. Varlık sorusunun anlamlı bir biçimde sorulabilmesi için Dasein ontik bir önceliğe sahiptir, zira bu varolanın varlığı varoluş gibi özel bir nitelik sunmaktadır. Varoluşun Dasein için belirleyici olması ise, söz konusu varolanın ontolojik bir önceliğe sahip olduğunu akla getirir. Diğer yandan, "Kim?" sorusunun yanıtı belli bir doğaya sahip varlığın ne-liği tartışlarak günyüzüne çıkartılamaz. Bir başka deyişle insan varlığını kendisine biçilmiş sabit bir doğa, yani "mevcudiyet" veya "ne-lik" [essentia; Was-sein] terimleri ile anlamaya çalışmamak gerekir ${ }^{3}$, zira varlığı önontolojik olarak mevcudiyet terimleri üzerinden anlayan yine Dasein'ın kendisidir:

... Dasein'a ... Dasein gibi olmayan varolanların da varlığını anlamak ait bulunmaktadır. Bu yüzden Dasein'ın üçüncü önceliği, onun, her türlü ontolojilerin olanaklılığının ontik-ontolojik koşulu olmasıdır. (Heidegger, 2008, s. 14).

İnsan varlığının ontolojik altyapısını teşkil etmekte olan Dasein'ın kim-lik terimleri üzerinden anlaşılması hususundaki ısrar, aslında, Dasein'ın zamansallığını belli bir anlamda gözardı eden statik bir tanıma

\footnotetext{
2 Varlığın herhangi bir nesne, fenomenolojinin ise Husserl'in iddiasının aksine herhangi bir bilim olmadığını anlatmak üzere Heidegger şöyle yazar: "Fenomenoloji, ontolojinin teması olacak olana hem erişim minvali, hem de onun teşhir edici belirlenim minvalidir. Ontoloji sadece ve sadece fenomenoloji olarak mümkündür. Fenomenin fenomenolojik kavramı, kendini gösteren, yani varolanın varlığ1 demektir. . . Ve buradaki 'kendini gösterme' öyle herhangi bir kendini gösterme değildir, 'gibi görünme' ise hiç değildir. Varolanın varlığı, 'görünür olmayan', 'ardında' başka bir şeylerin durduğu bir şey ise asla olamaz" (Heidegger, 2008, s. 37).

3 "Geleneksel anlamda existentia, ontolojik olarak mevcut-olma gibisinden bir anlama sahiptir ki, böyle bir varlık minvali, Dasein niteliğindeki söz konusu varolana özsel olarak uygun değildir" (Heidegger, 2008, s. 44). Çünkü bu tip bir varoluş, öz ya da ne-lik [essentia] terimleri üzerinden kavramsallaştırılan ve Dasein'ın varlık yapısını özelliklerinin taşıyıcısı olan bir töz [subjectum; hypekeimenon] olarak değerlendiren bakış açısına davetiye çıkartmaktadır, ki Dasein'ın bir şey olmadığı konusunda ısrarcı bir tutum takınan Heidegger'in dikkat çekmeye çalıştığı husus tam olarak budur.
} 
değil, dinamik bir yorumsama edimine davetiye çıkarır niteliktedir, ki söz konusu yorumsama edimi, Dasein analizini hedefleyen, bu anlamda da her türlü ontolojinin kaynağına inen "fundamental ontoloji" den başkası değildir (Heidegger, 2008, s. 13). [T1 ve T4] Dasein, kendini tanımlama konusunda dişsal herhangi bir mevcudiyeti temel alma şansı olmayan varolandır. $\mathrm{Bu}$, onun varlığ 1 anlayan ve sorabilen tek varolan olmasıyla aynı şeydir. Heidegger bunu, yukarı da dile getirilmiş olduğu gibi, "Dasein'ın özü onun varoluşudur", diye ifade etmektedir (Heidegger, 2008, s. 44) Bir başka deyişle, Dasein, varlığ kendisine gerçekleştirilecek bir görev olarak yüklenmiş varolandır. Dünyadaki tarihsel ikâmeti esnasında ortaya koyduğu tüm eylemler onu bir kim-lik olarak zaten ortaya koyar. Dasein'ın yaşaması ve kendini tanımlaması bir ve aynı şeydir.

Tüm bu ifade edilenler Dasein'ın temelinin, özünün bir şey olmadığını [no-thing] göstermek içindir. Varlık ve Zaman'da geçen ontikexistentiell ve ontolojik-existential ayrımı, tam da bu noktada işimize yarayabilir. Şöyle ki: Varlık bir varolan değildir. Bugüne kadar süregelmiş olan ontolojik gelenek varlığı bir varolan konumuna yerleştirerek varlık ve varolanlar arasındaki "ontolojik fark" a duyarsız kalmıştır. Heidegger, ontik karakter arz eden mevcudiyet temelli Batı metafizik geleneğinin insanı da varolanlar içinde herhangi bir varolan olarak değerlendirdiğine ikna olmuş görünmektedir. Söz konusu gelenek insanı bir şey olarak kavrar. Dolayısıyla Heidegger, insanın ön-ontolojik bir varlık anlayışına dayalı özkavrayışını "existiell” olarak nitelemeyi uygun görmüştür:

Dasein'ın şu veya bu şekilde davranış gösterebildiği ve bir şekilde her daim belirli bir davranış içinde bulunduğu varlığına [That kind of Being towards which Dasein can comport itself] varoluş diyoruz. Öte yandan söz konusu varolanın özünü belirlerken, konusal içeriklerden oluşan "ne"liklerin sıralanması yoluna gidemeyiz. Çünkü söz konusu varolanın özü, hep kendi varlı̆̆ını bizatihi kendisininki olarak var etmesinde yatar. Bu yüzden Dasein terimi, bahse konu varolanı adlandırmak için seçilmiş salt varlık tâbiridir [purely an expression of its being; als seiner Seinsausdruck] (Heidegger, 2008, s. 12).

Dolayısıyla, ontik-existentiell anlayışın dayatmakta olduğu şeyleştirilmiş insan kavramsallaştırmalarının tersine, [T5] Dasein temeli hiçlik [das Nichts; nothing $]^{4}$ olan varlıktır, zira o, yukarıdaki alıntıda da belirtildiği gibi kendi varlığını kendisininki olarak inşa edendir. Sıkıntı

\footnotetext{
${ }^{4}$ Heidegger'in burada dikkatimize sunmaya çalıştı̆ı incelikli noktayı rahatlıkla görebilmek açısından eklem noktası vurgulanarak yazılan İngilizce no-thing sözcügü Almanca Nichts'ten daha iyi iş görebilir. Zira no-thing kullanımı hem Dasein'ın hiçlik temelinde varolmakta oluşunu, hem de onun bir şey olmadığını tek seferde dile getirmektedir. Dasein'ın ön-belirlenmiş bir doğaya sahip olmaktan uzak oluşunun altını çizen bu ifadeyi Türkçe'ye hiçlik yanında şey-olmama olarak da tercüme etmek pekala mümkündür.
} 
ise, anksiyete ile beraber, ölüme ya da tamamlanmışlığa giden Dasein'ın kendini gerçekleştirme yolunda karşılaştığı hiçliğe verdiği bir yanıt olarak okunabilir. Bu noktada ilk olarak bir kendini gerçekleştirme fenomeni olarak sıkıntıyı açığa çıkartmak adına, Husserl tarafından kullanılmış olan Erfüllung (doyurma, gerçekleştirme) kavramını gündeme taşımak yararlı olacaktır.

\section{Husserlci Erfüllung Kavramı}

Heidegger'in ortaya koyduğu sıkıntı fenomenini Husserl'in kategorik sezgiyi açılamak üzere seferber ettiği "yerine getirme", "gerçekleştirme" (Erfüllung) kavramsallaştırması üzerinden anlamaya çalışmak da olanaklıdır. Algılama esnasında duyu organlarının sağladığı verilerin her daim tamamlanması, bütünlenmesi söz konusudur. Bir kitap gördügüumü söylediğimde aslında gördüğüm bir kitap kapağından başka bir şey değildir. Görüş alanıma girmeyen ve arka planda kalan kısmı kitap nesnesini meydana getirecek biçimde ekleyen zihnimden başkası değildir. İfademe [expression] konu olan her daim görüde [intuition] verili olanı tamamlar, ona göre bir fazlalık içerir. Benzer bir biçimde "halının üzerinde bir kedi uyuyor" dediğimde halı, kedi ve uyumanın tarafımdan görülmekte olduğunun, ama "üzerinde" ve "bir" ifadelerine konu olan varlıkların kendilerini bana duyu verisi olarak sunmadıklarının altını çizmek icap eder. Bilincin kategorileri devreye girmiş, dışarıdan gelen veriyi bütünlüklü bir nesne durumu şeklinde dişa vuran bir yargıya tamamlamak üzere kendilerine düşen rolü oynamışlardır. Nesne ya da nesne durumunun bütünlüğüne gönderme yapan ve Husserl tarafından "ifade" olarak tanımlanan yönelimsel edim bazen tamamen boş kalır; çoğu zaman ise kısmî olarak da olsa görü (sezgi) tarafından doldurulur, doyurulur. ${ }^{5}$ Bu noktada beklentiler ve onların karşılanmasıkarşılanmaması gibi bir durum söz konusudur. Peki Heidegger'in sıkıntıya ilişkin olarak söylediklerinin burada anlatılanlarla ne gibi bir ilişkisi vardır?

Üzerinde konuşmuş olduğumuz Husserlci resim bilinç ve nesnesi arasındaki yönelimsellik bağıntısını anlamaya dönük epistemolojik bir çerçeve sağlar. Alg1 olarak adlandırılan zihinsel edimi merkeze

5 "İmlemsel yönelim daha ziyade her tür doluluktan yoksundur: imlemsel yönelime teşhis [identification] üzerinden ilk kez doluluk taşıyan ise görüsel sunumdur [intuitive presentation]. İmlemsel yönelim yalnızca nesnesini işaret etmekle yetinirken, görüsel yönelim aynı nesneye 'mevcudiyet' kazandırır; bir başka deyişle, nesnenin doluluğu gibi bir şeyi mümkün kılar” (Husserl, 1970, s. 728). 
yerleştiren ve insanı bu minvalde anlamaya çalışan Husserl'in ortaya koyduğu fenomenolojik yaklaşımın Heideggerci ikâmesi fenomenolojiyi epistemoloji yerine ontolojinin yöntemi olarak ele alır. Heidegger için önemli olan, bilgi yönelimli aşkınsal öznenin içinde hareket alanı bulduğu daha geniş varlık zeminini ortaya koymaktır. Fırlatıldığı dünya tarafından yutulmuş veya kuşatılmış, amaca dönük ve ölecek olmaktan dolayı kaygılı insan varlığının varoluşsal çözümlemesi, söz konusu bilişsel öznenin varlık zeminine karşılık gelen açıklık/oradalık'ın kavranma çabası olarak anlaşılmalıdır. Mevzubahis çaba, Heidegger'in 1927 tarihli baş yapıtı Varlık ve Zaman'da "temel ontoloji" [Fundamentalontologie] ya da Dasein analitiği [Daseinsanalytik] olarak adlandırdığı yorumsamacı/fenomenolojik varoluş [Existenz] araştırmasına denk düşmektedir (Heidegger, 2008, s. 13).

Dasein Heidegger'in insan varoluşunu anlatmak için kullandığ 1 sözcüktür. Varoluşları önden belirlenmiş bir özün [das Wesen; essence] zaman içinde kendini açışından ibâret olan diğer varolanların aksine Dasein'ın varoluşu özünden önce gelmektedir. Bu ise, pozitif bilimler ve felsefî antropolojinin yeltenmiş olduğu üzere insana sabit bir doğa yakıştırma çabasının her daim boşa çıkacağı şeklinde yorumlanmalıdır. Bir diğer deyişle Dasein'ın "ben" $i$, ben-olmayanları dışarıda bırakacak içe kapalı, izole bir içsellik alanı; değişen halleri ve görünümleri, yani yüklemlerinin taşıyıcısı olan sabit bir töz (subjectum) olarak düşünülemez. Ben-olmama, içinde kendini kaybettiği kamusal alandan kendine dönmeye ve de ben olmaya çalışan Dasein'ın varoluşsal özüne ait olarak tahayyül edilmelidir:

Buradaki "ben", ilgili fenomenal varlık bağdaşımı içinde belki de kendisinin "tersi" olduğunu meydana vuran bir şeyin bağlayıcı olmayan formal ilâmı anlamında anlaşılmalıdır. Dolayısıyla "ben-değil" dendiğinde de, özü gereği "benlik"ten mahrum olan bir varolandan bahsediliyor değildir. Bu durumda bizatihi "ben"in belirli bir varlık minvalinden, örneğin kendini kaybetmişlikten söz ediliyor olunmaktadır (Heidegger, 2008, s. 122).

Kaybetmiş olduğu benliğinden sahih benliğine dönme çabası içinde olan Dasein'ın varlığı, tam da söylenen anlamda kendisine gerçekleştirilmeyi bekleyen birödev olarak sunulmuştur. Bu ödev "hayatın anlamı" olarak adlandırılabilirse eğer, sıkıntı, söz konusu anlamın ortaya koymakta olduğu sorumluluğun yerine getirilememesinden kaynaklı kökensel bir haletiruhiye (Grundstimmung) olarak karşımıza çıkar. Bu, 
zaman zaman bir nesne ve bu nesnenin dayatmakta olduğu iş ve amacın gerçekleştirilememesi olarak tezahür etse de, derin ontolojik mânâda kendi varlığının hakkını vermeye çalışan Dasein'ın hakkı verilecek sabit bir zeminden yoksun oluşu karşısında duyduğu dehşet, yani hiçlik deneyimi olarak kendini ortaya koyar. Dünya Dasein'ı reddeder, onu boşluğa geri fırlatır. Bu esnada zihinsel yönelimin muhatabı geri fırlatılmış olmaktan kaynaklı sıkıntı değil, reddiyenin kaynağı olan nesne olduğu içindir ki, söz konusu haletiruhiye reflektif bir tavırla ele alınamaz; içebakışa konu olan bir nesne olarak incelenemez.

\section{Sıkıntı ve Varoluşsal Semantik}

İşaret ederek gösterme semantiğin kendisini temel aldığı en ilkel referans biçimi olarak görülebilirse, Heidegger'in Dasein'a ait pek çok varoluşsal moment yanında sıkıntı için de farklı bir gösterim mantığı talep etmekte olduğunadikkat edilmelidir. Bumantıkparmağınkendisinedoğrultulduğu nesneyi hedef almaktan çok, bu esnada dikkatin varoşlarında kalanı, karşıya-konulmuş olanın yancısını sorgulama konusu etmeyi amaçlar. Bu noktada portresini çıkartmaya çalıştığımız araştırma yönteminin ne denli çetrefil olduğunu vurgulamak için şunu söylemek sanırım yeterli olacaktır: Dil ve teori, temel karakteristikleri ve bağlantıları üzerinden açığa kavuşturmayı umduğu dünya öğesini karşıya koyup işaret eder, yani nesneleştirir [Gegenstand, object]. Heideggerci fenomenolojinin talebi ise açığa kavuşturulmaya çalışılanın, ortam dil olarak kalmaya devam etse de, nesne haline getirilmesinden kaçınmak olarak tanımlanabilir. ${ }^{6}$ "Şeyin kendisi"ni [Sache selbst] açıklığa getirmek, onu, ancak ve ancak zihnin parmakla göstermekte olduğu doğrultudan saptırmakla mümkün olabilir. Bu ise, gözü nesnede sabit tutarken dikkati yanal elemanlara çevirme becerisini sergileyebilmek gibi bir harekete benzer.

Aslına bakılacak olursa sabitlenmiş göze rağmen yer değiştiren dikkat benzetmesi ele almaya çalıştı̆̆ımız konu açısından sadece bir yaklaşım mesafesi üretiyor olmanın çok da ötesine geçemez. Biraz daha cüretkâr bir tutum takınılıp, Heidegger açısından açıklı̆̆a taşınmaya

\footnotetext{
Müşahede edici düşünümün ya da içe bakışın kendini kendi hiçliği ya da temelsizliği temelinde kuran — yani bir şey olmayan, mevcudiyet terimleri ile anlaşılamayan—bir varolan olarak Dasein'ın nesneleştirilemeyeceğini anlatmak için Heidegger şu retorik soruları sorar: "Dasein'a erişimin, edimlerdeki ben üzerine yalın ve müşahade edici bir düşünüm üzerinden gitmesi gerektiği sahiden $a$ priori bir besbellilik midir? Yoksa eksistensiyal analitik bakımından Dasein'ın söz konusu 'kendini veriş' minvali bir yoldan çıkarma, hem de Dasein'ın bizatihi varlı̆ğ üzerinde temellenen bir yoldan çıkarma mıdır?" (Heidegger, 2008, s. 121)
} 
çalışılanın, yani fenomenolojik anlamda fenomenin (şeyin kendisinin) tam da zihne ait hayâlî parmağın işaret etmekte olduğu yönün tersinde konuşlu olduğunun altını çizmek icap eder. Üzerinde durulan fenomen sıkıntıdır ve sıkıntı kendisinde kalamadığımız, huzuruna çıktığımız anda arkamızı dönüp sıvışmaya çalıştığımızdır. Bedensel terimlerden örülü bir analoji üzerinden konuşmaya devam edecek olursak o, parmağımızla işaret edip baktığımız değil, sırtımızı dönüp kendisinden kaçtığımızdır.

Varoluşa-dair bir yaklaşımdan gelerek bakıldığında düşkünlük [Verfallen; falling], kendi-olmanın sahihliğini örtüp kapar ve bir kenara iter. Oysa bu kapalılık, açımlanmışlı̆ıı yoksunluk halinden başka bir şey değildir. Dasein'ın kaçışı kendisinden kaçıştır ve bahse konu açımlanmışlık kendisini fenomenal olarak burada açımlar. Tam da kendisinden kaçış yüzünden Dasein kendi 'peşine' düşer. Yani Dasein kendisine ontolojik bakımdan özsel olarak ait olan açımlanmışlık sayesinde esasen kendi kendisiyle karşı karşıya kaldığı takdirde kendinden kaçabilmektedir. Bahse konu düşkün yüz çevirme sırasındaki kaçışın nedeni, elbette ki kavranılmış olmaz, hatta ona doğru yüzünü döndürerek dahi tecrübe edilmez. Fakat tam da ondan yüz çevirdiğimiz zaman 'şurada' [Da; there] açımlanmış olmaktadır" (Heidegger, 2008, s. 195).

Yukarıdaki alıntı, dünyanın bütün olarak anlamını ve ehemmiyetini kaybedip geri çekilmesi üzerinden yaşantılanan hiçlik deneyimini ortaya koyan endişeyi [Angst; anxiety] betimlemekte olsa da, bu söylenenlerin tamamı derin sıkıntı adı verilen haletiruhiyeye de uygulanabilir. ${ }^{7}$ Varoluşsal özü hiçlik olan Dasein'ın kendini bir doğaya sahipmiş gibi tasavvur etmesi, onun kendisini kökeninde yatan hiçlik üzerinden değil, mevcudiyet üzerinden anladığını gösterir, ki Heidegger bu durumu "düşkünlük" diye niteler. Burada üzerinde yoğunlaşmamıza, içinde ikâmet etmemize izin vermeyen fenomeni alıp nesne olarak karşıya koymak, nesne hâline getirmek, onu orijinalliğinden sıyırıp dönüştürmek; sırf bilme yönelimli varlıklar olduğumuz için onu olduğu haliyle görmeyi reddetmek gibi bir durum söz konusudur. Yapılması gereken daha ziyade "insanın bilincini betimlemektense, ondaki Dasein'ı uyandırmaktır" (Heidegger, 1995, s. 174). Heidegger'e göre varoluşsal bir haletiruhiye olan sıkıntı her şeyden önce mâruz kalınan, içine düşülen sıkıntıdır. Bir

\footnotetext{
7 Varoluşsal endişe ve derin sıkıntının aynı haletiruhiyeye karşılıp gelip gelmediği sorusunu yanıtlamak uzun bir tartışmayı gerektirebilir. Her ikisi de Dasein'ı sahih kendiliği, yani hiçliği ile buluşturdukları ölçüde, bu yazı boyunca aynı haletiruhiye gibi düşünülmüşlerdir.
} 
başka deyişle, nesne hâline getirilmiş sıkıntı evcilleştirilmiş olur ve içine düşülen, yani yaşantılanan sıkıntı olma hâlini kaybeder: Şu halde, sıkıntıyı anlatabilmenin en iyi yolu dilsel bir ortam (yazı ortamı) içinde dahi olsa ona mâruz kalmanın bir yolunu bulmaktır. Bu ise belli bir varoluş hâlini öz terimleri üzerinden kurmayı reddedip yine varoluş üzerinden anlamlandırmakla mümkün olacaktır. Varoluşsal düzlemde sıkıntı fenomenini açığa vuran noetic bileşen kaçınma veya karşısında tabanları yağlayıp sıvışmadır. Bu anlamda söz konusu tüyme hareketinin kendisi bir işaret etme biçimi olarak varoluş̧̧u sıfatıyla niteleyebileceğimiz yeni bir semantiğin ilksel bileşenlerinden biri olabilir gibi görünmektedir.

"Alles Versagen ist in sich ein Sagen, d.h. Offenbarmachen", ya da İngilizce metindeki ifadesiyle: "All telling refusal is in itself a telling, i.e., a making manifest" (Heidegger, 1995, s. 140). Metafiziğin Temel Kavramları adlı metinde dile getirilen bu ifadenin Türkçe karşılığı aşağı yukarı şudur: “Dile getirilmesi mümkün olmayanı dile getirme yolunda sergilenen her çaba öyle ya da böyle bir dile getirmedir; açığa çıkarmadır". Varlık ve Zaman'da geçen temel ontolojik ifadelerin birer kategori, yani varlığın çeşitli anlamlarını veren kavramlar olarak değil de biçimsel belirteçler ya da formel indeksler (Formale Anzeige) olarak tanımlanmalarının nedeni tam olarak budur. Dilsel kavramlar zihnin huzuruna çıkartılmış nesneyi muhatap alırken, existential'ler olarak da adlandırılan bu belirteçler tam da zihinsel gözün görmediğini konu etmenin bir yolu olarak öne çıkarlar. ${ }^{9}$

Nesne olanın varlığının tek bir anlamı vardır: mevcudiyet (presence). Mevcut olan zihnin dikkatine sunulmuş olandır ve zihnin odaklanma işlemini gerçekleştirdiği zaman kesitine hapsedilmiş durumdadır. $\mathrm{Bu}$ zaman kesiti de "şimdi" adı verilen zamansal birimden başkası değildir. Zihin ve nesne arasındaki ilişkiyi temele alan ve şimdilerden oluşan düzgün doğrusal zaman anlayışını terketmeden periferde kalan

\footnotetext{
8 "Telling refusal” ifadesini mota mot çevirecek olursak "(duyguları, düşünceleri, vs.) açığa çıkartan reddediş” gibi bir anlam elde ederiz. Bu, nesne olarak görünüme gelmeyi reddeden fenomenin, yarattığı dirençte kendini açı̆̆a vurması gibi anlaşılabilir.

${ }^{9}$ Metafiziğin Temel Problemleri adlı eserinde Heidegger, sıkıntıya yönelik "bu sorgulamanın, tüm bilimsel soruşturmalara zıt olarak, belirli bir bilgi sahasına yerleştirilemeyeceğini, ya da böyle kapalı bir alan içinde etkinleştirilmesinin mümkün olmadığını" söyler ve şunu da ilâve eder: "Bu sorgulama, kendine ait soruşturma sahasını ilk olarak sorgulama ediminin ifâsı esnasında oluşturur ve yine, söz konusu soruşturma sahasını açık tutmaya yalnızca sorgulamanın ifâsı süresince muvaffak olur" (Heidegger, 1995, s. 174). Bir başka deyişle, kendileri vasıtasıyla sıkıntı fenomenini sorguladığımız kavramlar, yani formel indeksler söz konusu sorgulamayı mümkün kılarlar. Diğer yandan ise, etkinliklerinin devamını sorgulamanın devam etmesine borçludurlar. Bu bize, sıkıntı fenomeninin bilince verili bir nesne olmadığını göstermelidir.
} 
sıkıntıyı fenomenolojik incelemenin konusu kılmanın bir yolu yoktur. Zira "şimdi"ye hapsedilmiş Dasein mevcudiyet ontolojisi üzerinden anlaşılacak doğal bir varolana indirgenmiş olur. Bu husus bizi Heidegger' in zaman anlayışını bir kez daha gözden geçirmeye sevkeder.

\section{Dasein'ın Kökensel Zamansallığı}

Sıkıntı fenomenini anlayabilmek için ardarda sıralanmış şimdilerden oluştuğu düşünülen nesnel zaman ya da geleneksel zamanın ontolojik koşulu olan kökensel zamansallık fenomeninin açımlanması gerekmektedir. Noktasal şimdilerin arka arkaya dizilmelerinden oluştuğu için şimdi-zamanı olarak da anılan geleneksel zaman Heidegger' in "dünyazamanı" diye adlandırdığı zaman tarafından; dünya zamanı ise Dasein'ın "ekstatik-ufkî kökensel zamansallığı" tarafından temellendirilmektedir.

Bilim ve sağduyunun ortak anlayışında şekillenen geleneksel zaman kavrayışı Heidegger tarafından Aristoteles'in şu tanımına dayandırılır: "Aslında zaman şudur: önce ile sonraya göre devinim sayısı" (Aristoteles, 2012, s. 191) [T7]. "Henüz" ve "artık" gibi zamansal ifadelerin "henüz şimdiye taşınmamış" ve "artık şimdi olmayan" şeklinde anlaşılmaları uygunsa, gelecek ve geçmişi de içine almakta olan bu zaman kavrayışının buna rağmen "şimdi-zamanı" olarak adlandırılıyor oluşunu normal karşılamak gerekecektir. ${ }^{10}$ Sayılıyor olması geçiyor oluşunu, geçiciliğini, akışkanlığını imâ eden bu fenomende sabit kalan nedir ki, ona hâlâ zaman gibi bir isim verebiliyoruz? Bu soruyu sormak, özüne hareket katmış olduğumuz bir fenomenin ne bakımdan kalıcılık içerdiğini sormakla birdir. "Zaman nedir?" sorusu, akışkanlığı es geçecek biçimde zamanı bir bütün olarak ele alır ve onu şeyleştirip nesne hâline getirir; onda değişmeden kalan özsel öğenin ne olduğunu sorar. Yanıt ise açıkça "şimdi" den başka bir şey değildir. Zaman kendisi vasıtasıyla hareketi saydığımızdır; "Aristoteles cephesinden şu saf bir iddia olarak görünür, ki zamanın hareketle

10 "Aristotelesçi zaman tanımı ilk olarak şöyle de formüle edilebilir: zaman, önce ve sonra bakımından deneyimlenen hareketle bağlantılı olarak sayılan şeydir. Fakat bu şekilde sayılanlar şimdi olarak açığa çıkarlar. Ne var ki bahsi geçen bu şimdiler yalnızca önce ve sonra ufkunda dile getirilir ve anlaşılırlar" (Heidegger, 1982, s. 246). Bu söylenen çok önemlidir, zira Bergson'un Aristotelesçi zamanı kavrayışının aksine (şimdi-noktalarının aritmetik toplamından müteşekkil olup mekana dönüştürülmüş zaman), Heidegger'in şimdi-zamanını büyük filozof ile özdeşleştirmekten kaçındığına delâlet eder. Heidegger'in amacı, bilâkis, şimdinin geçmiş ve geleceğe, geçmiş ve geleceğin de şimdi ve birbirlerine atıfla mümkün hale gelebileceğini öne sürmesini sağlayan ekstas fikrini Aristoteles'e borçlu olduğunu göstermektir. [T8] 
bağlantılı olarak sayılan olduğu farz edilir (Heidegger, 1982, s. 239) [T8]. Hareketi ise homojen biçimde yanyana dizilmiş şimdileri sayarak ölçeriz. Bu durumda hareketi mi zamanla, zamanı mı hareketle açıklıyor olduğumuz sorusu yanitlanmadan kalmaya mahkum bir soru olarak gelip karşımıza dikilir. Zamanın özünü sorgulamak, her ne kadar önyarg1 bildirmeyen nötr bir tavır alma olarak görünüyor olsa da, soruya konu edilmekte olan fenomene bir nesne olarak yaklaşılabileceğini bildiriyor olması bakımından düşündügümüz kadar masum bir eylem değildir. Zira zaman bir nesne ise, onun da her nesne gibi dünya-içinde yer alıyor olması zorunludur. Ama açıktır ki, hareket ve değişimin dünyanın ontolojik özyapısına dahil edilmesi gerekliliği ölçüsünde zamanı dünya-içre bir varolan olarak kavramak mümkün değildir. O halde zaman nerededir? Saymakta olduğu dünyevi hareketin neresinde durmaktadır? Kendisini sayana göre nerede konumlanmıştır?

Zaman saymaktan önce, içinde yaşadığımız dünyayı ve dolayısıyla bu dünya içinde kendi konumumuzu tanzim etmeye yarar. Heidegger' in "dünya zamanı" dediği zaman, zamanı içinde yer alacağımız toplumsallığın gerekleri ve bu gereklerin bize kendilerini dayatıyor oluşlarını dikkate alır. Bu anlamda söz konusu zaman, takvimlendirme üzerinden her daim dünyaya bağlanmış bir zamandır. Nesnel zaman "saat üçte" demeyi zamanı bildirmek bakımından kâfi görürken, dünya zamanı aynı şeyi "buluşmayı kararlaştırdı ğımız saat" diye ifade etmenin uygun olacağını öngörür. [T8: counting time: Aristoteles; time-reckoning: zamanı hesaba katma; ayrica bkz: dipnot 10]

Diğer yandan, dünya zamanı dahi Heidegger'in istediğini vermeye yetmez. O, "şimdi" nin mümkün olabilmesini sağlayan ufku açımlayan, daha kökensel bir zaman kavrayışının peşindedir. Bu noktada vurgulayacağı temel husus, şimdinin geçmiş ve geleceğe; geçmiş ve geleceğin de geri kalan iki zaman kipine gönderme yapmaksızın anlamlı bir bildirimde bulunmakta yetersiz kalacaklarıdır. Sözü geçen üç zaman kipinin birbirlerine her daim gönderme yapıyor oluşları, Heidegger tarafından kökensel zamanın "ekstasları" olarak adlandırılmalarına yol açmıştır. Zamanın üçlü ekstatik yapısı, insan varlığını bulunuş, söz ve anlama adıverilen ontolojik modların bütününden meydana gelen ihtimam yapısı içinde, zamansal ve sınırlı [finite] bir varlık olarak kavramamızı sağlar. İnsanın kendi seçmediği bir dünyaya atılmışlığının temel ifadesi olan haletiruhiye, ve bir haletiruhiye olarak sıkıntıyı anlamak istiyorsak, zamanın bu derin ontolojik kavrayışından yola çıkmamız gerektiği açıktır. 
Ama bizim amacımız, tam tersine, söz konusu zaman anlayışına varmak için sıkıntı fenomenini işe koşmak olacaktır.

\section{Langweile olarak Sıkıntıya ilişkin Genel Fenomenolojik Yaklaşım}

Sıkıntı her şeyden önce bir haletiruhiye [mood] olduğu içindir ki, onu, Dasein'ın varoluşsal özünü meydana getiren ihtimamın [Sorge; care] anlama [Verstehen; understanding] ve söz [Rede; discourse] ile birlikte üçlü yapısını oluşturan bulunuş [Befindlichkeit; state-of-mind] üzerinden gündeme taşımak gerekir. Burada bulunuşu "birinin içinde bulunduğu durum" (Gelven, 1989, s. 80) ya da Almanca "Wie befinden Sie sich?", yani "Kendinizi nasıl hissediyorsunuz?" kullanımları üzerinden kavrarsak, haletiruhiye ve bulunuş kavramları arasındaki ilintiyi algılamamız daha kolay olacaktır.

Heidegger'in bizi sıkıntıyı nesneleştirip anlamaya değil, ona mâruz kalmaya davet etmesinin temel nedeni, nesneleştirme de dahil olmak üzere her türlü anlama etkinliğinin arka planında bir haletiruhiyenin yatıyor olmasıdır: "Bulunuş hep bir anlayış iledir, fakat özelliği onu örtbas etmesidir. Anlamak her daim bir haletiruhiyeyledir" (Heidegger, 2008, s. 150). Dünyayı bir nesne olarak karşıya koyup algılamaya, onun bilgisini edinmeye çalışan tarafsız ve yansız bakış dahi, önüne koyduğu nesne alanını belli bir gerekçe ile değerlendirmeye alır. Bir başka deyişle, gerekçesi olmayan bir zihinsel yönelmişlikten bahsetmenin imkânı yoktur. Her algılama aynı zamanda bir seçim yapmadır ve bu da algılanmak üzere içinden seçim yapılan alanın dünyanın bütününü açığa vuran bir haletiruhiye arka planında öne çıkarıldığı anlamına gelir. Şu halde Husserlci aşkınsal bilincin kayıtsız yönelimselliğinin art alanında Heidegger'in vazetmekte olduğu dünyanın bütünsel açımlanmışlığ yatmakta; söz konusu açımlanmışlığı ise bulunuş mümkün kılmaktadır. ${ }^{11}$ Heidegger haletiruhiyeden bağımsız, nesnel ve kayıtsız bir dünyaya

\footnotetext{
${ }^{11}$ Matthew Ratcliff, Heidegger'in anlamayı bulunuştan daha öncelikli bir varoluşsal moment olarak değerlendirmiş olduğu hatırlatması yapsa da bu görüşe şöyle karşı çıkar: "Böylelikle, her ne kadar anlama verili bir varolanın belli bir şekilde ehemmiyetli [significant] görünüp görünmediğini belirliyor ise de, aynı varolanın aynı biçimde ehemmiyet olabilmesini ya da olamamasını belirleyemez. İllâ biri öncelikli olacaksa, anlama üzerinde önceliği olanın haletiruhiye olduğunu belirtmek gerekir, zira içinde anlamanın iş göreceği olanaklılık alanını şekillendirmekten sorumlu olan haletiruhiyedir" (Ratcliff, ss.161-2). Zaten Varllk ve Zaman'dan iki yıl sonra Heidegger, Ratcliff'in bu iddiasını destekleyecek tarzda şunu yazacaktır: "Bulunuşlar, içinde kendimizi şu ya da bu şekilde nizama sokulmuş [disposed] olarak bulduğumuz kökensel tarzlardır. Bulunuşlar, kendilerine uygun olarak birinin o ya da bu şekilde olduğu 'nasıl'a [Wie] karşılık gelirler”' (Heidegger, 1995, s. 67).
} 
yönelmişlik halini reddeder, zira bir "haletiruhiyeye hakim olmak, herhangi bir haletiruhiyeye sahip olmaksızın gerçekleşmez, aksine hep belirli bir karşı haletiruhiyeden hareketle olur" (Heidegger, 2008, s. 144).

Heidegger, Metafiziğin Temelleri'nde sıkıntı analizine sıkıntının zamanla ilişkisini vurgulayarak başlar. Almanca'da Langweile (ing. whiling long) süregitmenin uzaması, zamanın lastik gibi genişlemesi, geçmek bilmemesi anlamlarına gelmektedir (Heidegger, 1995, s. 78). Dasein'ın zaman ile ilişkisi, daha önce belirtilmiş olduğu gibi, zamanın onun varoluşsal özüne ait olması olarak düşünülmelidir. Dasein'ın özü varoluşudur ve varoluşun özü ise zamandır. Bu söylenen ne anlama gelmektedir?

Geleneksel anlayış uyarınca zaman, zamandışı öze sahip özneye ait bir yeti [faculty] olarak düşünülmüştür. İnsanın özünün düşünce [res cogitans], ve düşüncenin özünün ise, duyusal olana zıt olarak zamandışılık, değişmezlik olduğu hatırlanacak olursa Heidegger' in anlatmaya çalıştığ şey daha iyi anlaşılır. Ona göre durum daha ziyade şudur: Sabitlenmiş, tamamlanmış, bitmiş ve bu sayede de zamanın dışında kalmış bir doğaya sahip olmayan Dasein'ın kim-liği tamamen onun varoluşuna bağlıdır ve varolma ara verilebilir, askıya alınabilir bir fenomen değildir; bir başka deyişle, zamanın zamanlamasının amansızlığı ölçüsünde Dasein kontrolü elden kaçırma tehlikesiyle ${ }^{12}$ her daim burun buruna yaşar. $B u$ anlamda zamanın Dasein'a değil, Dasein'ın zamana ait olduğunu belirtmek daha uygun olacaktır. "Zamanım var/yok" türündeki gündelik ifadelere zıt bir biçimde Dasein'ın zamana ait olduğunu iddia etmek, hiç kuşku yok ki Dasein'ın zaman içre [intratemporal] bir varolan olduğu vehmini de yaratmamalıdır. Önermeler ve sayılar gibi zaman-ötesi [supratemporal] veya ebedî [eternal] olarak nitelenenlerin tersine zaman içre veya değişken bir varlık tarzı arz eden olaylar, nesneler, süreçler gibi varolanlardan bahsetmek ve bu iki alanı birbiriyle ilişkilendirmeye çalışmak, Platon'dan beri felsefenin temel uğraşılarından birisi olagelmiştir (Heidegger, 2008, ss. 18-19). Fakat Dasein'ın zamansallığından (ya da temporalitesinden) bahsettiğimizde, onu zaman adı verilen mevcudun içine yerleştirilmiş ayrık bir mevcudiyet olarak kavrıyor da değilizdir. Durum daha ziyade şudur ki, Dasein'ın özü

\footnotetext{
12 "Kontrolü elden kaçırma tehlikesi”nden, sabit mevcudiyet terimleri üzerinden kavranamayacak olan Dasein'ın dünyayı ve kendisini kendi karşısına yine sabit ve mevcut bir nesne olarak koyamayacak olmasını anlamak gerekir. Dünyanın zamanı ile Dasein'ın zamanı arasında ortaya çıkması her daim olası olan uyumsuzluk (bkz. dipnot 13 Svendsen), Heidegger tarafindan arafta birakılma [Hingehaltenheit; being held in limbo] ve boşta bırakılma [Leergelassenheit; being left empty] kavramları ile ifade edilmiştir. Söz konusu kavramlar sıkıntının iki temel momenti olarak kavranmalıdır.
} 
zamansallıktır. Bir başka deyişle, varlığı anlayan varolan olarak Dasein, kendi tarzında varolmakla ürettiği zamansal ufka (Dasein'ın Da'sı) varlığın kendini yansıttı̆̆ı ayrıksı bir ontolojik birim olarak görülmelidir.

Dasein'ın zamana ait olduğunu söylemek demek, Dasein kendi zamansal özünü, yani varoluşunu kendine nesne yapamaz demektir [T9, T10]. Buna karşın "zamanım var/yok", "zamanı geçirmem lazım" gibi gündelik ifadeler, sanki söz konusu fenomen ondan bağımsız varlığımızın keyfiyetine, tasarrufuna kalmış gibi bir izlenimin doğmasına yol açarlar. Zamanı geçirmek, eninde sonunda "zamanı silkeleyip atmak" anlamına gelmez; durum daha ziyade şöyle tarif edilebilir: "Zamanı geçirmek, zamanı ittirip ilerletecek şekilde sıkıntıyı sürüp atmaktır"(Heidegger, 1995, s. 93) ${ }^{13}$. Ama zamanı ittirip ilerletme [driving time on] benzetmesinin bir anlamı yoktur, zira zamanın keyfiyetimize kalmış, ontolojisi mevcudiyet terimleri üzerinden önbelirlenmiş bir şey olduğunu söyleyemeyiz. Kaldı ki, sıkılmanın zamana mâruz kalma olduğu düşünülecek olursa, zamanı kontrolü altına almış bir varlığın nasıl olup da sıkılabileceği anlaşılmaz hale gelir. Zaman keyfime göre geçirebileceğim bir şeyse, sıkıntının da benim tasarrufumda olması gerekir, ki bu düpedüz saçmadır. Sıkıntı, bilâkis, geçirmem mümkün olmayan zamanı umarsızca geçirmek isteyişimle ilgili bir bulunuş biçimi olarak değerlendirilmelidir.

Heidegger'in açıklamasına göz atacak olursak Almanca'da zamanın uzamasından yakınmak yani sikılmak [Langweile haben], "sıla hasreti çekmek", "yuva özlemi duymak" anlamlarına gelmektedir (Heidegger, 1995, s. 80). Bu noktada dilin gündelik kullanımında açığa vurulmakta olanın şahitliğine güvenecek olursak şu soruyu sormamız gerekir: Sıkılma beyanında Dasein hangi gurbete savrulmuştur ve özlemini çekmekte olduğu yuva tam olarak neresidir? Sürüldüğü yerden geri dönememe teması olarak sıkıntı, bize felsefe yapıyor oluşumuzun gerekçesini sunması açısından da önem arzeder niteliktedir.

\section{Sıkıntı Türleri}

Heidegger'in tanımlamış olduğu üç tip sıkıntı deneyimi bulunmaktadır.

\footnotetext{
${ }^{13} \mathrm{Bu}$ tanımla ilgili olarak Heidegger şöyle bir değerlendirme yapar: "Lâkin daha ayrıntılı bir sorgulama sonucunda bu tanımın yanlış olduğunu görürüz. Zira zamanın bu ittirilip ilerletilmesinde ve sıkıntının sürülüp atılmasında, sıkıntı ile ilgili bir şey zaten söylenmiştir; bunlar zamanın ittirilip ilerletilmesi ve de geçip gitmesinin sağlanması [driving it by] momentleridir. Artık böyle yapmakla sıkıntıyı sürüp atıyor olduğumuzu söyleyemeyiz" (Heidegger, 1995, s. 95) zira ittirip ilerletme ve geçirme momentlerinin sıkıntının özüne ait olduklarını; bir başka deyişle sıkıntının bunların nedeni olmadığını söylemek icap eder.
} 
Birinciden üçüncüye doğru nesne belirsizleşmeye başlar ve nesnenin belirsizleşmesi ölçüsünde konu edilmesi gereken zamanın derinlik derecesinde artış olur. Sıkıntıyı kendisi üzerinden anlamamız gereken iki moment nesnenin kendini gösterip vermemesinden; ama buna rağmen Dasein'ı tutsak etmesinden ibârettir. Söz konusu momentleri Heidegger sirasiyla elde mevcut nesnenin dikkatimizi absorbe etmeyi reddederek bizi kendimize geri göndermesi olarak tanımladığı "boşta bırakılma" (Heidegger, 1995, s. 103) ve zamanın ayak sürümesi olarak betimlemeyi uygun gördüğü "arafta bırakılma" (Heidegger, 1995, ss. 99-100) olarak adlandirır.

Bir tren garında dört saat sonra gelecek olan treni bekleme mecburiyeti ile karşı karşıya olma durumu, Heidegger' in birinci sıkıntı tipini açıklamak için kullandığ 1 örnektir. Peronda dolaşılır, tuvalete gidilir, her 5 dakikada bir saate bakılır, ama zaman bir türlü geçmek bilmez. Bekleyenleri misafir etmek tren garlarının aslî işlevlerinden biri olsa da, bu nesne asıl amacı bir an önce trene atlayıp işine gücüne bakmak olan Dasein'ı memnun etmek şöyle dursun, ona bir tutukevi gibi gelir. Geç kalmış Dasein'ın sabırsızlığ1 artar, tren gelmeyi reddeder, ama Dasein'ı gar sayesinde esâret altında tutmaktan vazgeçmez. Heidegger ayrıca sıkıcı bir kitap okuma örneğini de gündeme getirir. İlginç bir şeyler sunmamakta direnen kitap Dasein'1 boşa çıkarırken, her an dökülüp gelmesi beklenen olağanüstü sayfalara ilişkin beklenti kitabın bir kenara fırlatılmasını engeller, Dasein'ı arafta bırakır (Heidegger, 1995, s. 93).

Bu durumu ontolojik terimlerle şöyle açıklamak da mümkündür: Dasein, kendi seçimine bırakılmamış olan bir dünyaya fırlatılmış (geworfenheit) varlıktır. İçinde yer almakta olduğu dünya, çoğu zaman bir nesne uzaklığı sağlamaktan ziyade Dasein'ı soğurup içine çeker, onu durmamacasına meşgul eder. Otantik zaman kavrayışına göre şimdinin kendini ortaya koyuşu, mevcudiyetin "burada ve şimdi" olarak kendini açması, gelecek planlarına dayalı olarak eylemekte olan Dasein'ın önünde açılan gelecek ile kendini içinde bulduğu dünyanın âşinalığından kaynaklı geçmiş momentlerinin etkileşmesi sayesinde mümkündür. Alet edevatın birbirlerine belli kullanım amaçları üzerinden referans ilişkileri ile bağlanmalarından mütevellit olan dünya, daha önce de belirtmiş olduğumuz gibi birliğini Dasein'ın nihai amacına, yani "hayatın anlamına" borçludur. Sıkıntının bu ilk hâlinde nesne yerine geçen bir dünya bileşeni, Dasein'ı, kendisi için hayatı anlamlı kılan amaca yürümekten meneder, onu kendini bütünleme yolundan alıkoyar. $\mathrm{Bu}$ 
durumda dünyanın kendini Dasein'a, onu kendine geç bıracak biçimde dayattığını söylemek mümkündür. ${ }^{14}$ Amaca yönelik Dasein şimdi'de kendini kaybedemez; zaman ayak sürür. Elde mevcut nesnenin kendini Dasein'a vermemesi ve onu boşa çıkartması, içinde bulunduğu dünyanın zamanı ile Dasein'ın zamanı arasındaki uyumsuzlukla birleştiğinde sıkıntı fenomeninin birinci türüne ilişkin ontolojik açıklama verilmiş olur. Tersinden düşünecek olursak, Dasein'ın gara varışı ile trenin kalkış saatleri örtüşmüş olsa sıkıntıdan bahsetmenin mümkün olmayacağ 1 bir durumun hâsıl olduğunu kabul etmek gerekir: “Sıkıntı yalnızca şu yüzden mümkündür, ki her şeyin. . . kendi zamanı vardır. Her şeyin kendine ait zamanı olmasa idi, sıkıntı diye bir şey de olmayabilirdi" (Heidegger, 1995, s. 105). Ama içinde bulunduğu çevreleyen-dünya (Umwelt) her daim zamansal bir eklemlenmeye, düzenlemeye tâbi olduğundan ve söz konusu işleyiş Dasein'ın bireysel zamanını kale almadığından, sıkıntının bu birinci bileşeninin her daim gündemde olmaya devam edeceği açıtır.

Sıkıntı veren nesnenin gayet belirgin olduğu bu durumdan daha derinlikli bir sıkıntı durumuna geçiş yaparsak, Heidegger'in şöyle bir örnek kullandığını görürüz: Bir partiye davetliyiz, gidip gitmeme konusunda yaşadığımız kısa bir tereddüt sonunda davete icabet etmeye karar veriyoruz. Akşam boyunca yenilip içiliyor, şakalaşılıp muhabbet ediliyor, her şey olması gerektiği gibi gidiyor. Ayrılırken övgüler duyuyoruz, memun kalıyoruz, tekrar görüşmek üzere sözleşiyoruz. Lâkin eve dönüp kendimizle başbaşa kaldığımızda; hele bir de o akşam yarım bırakmış olduğumuz işe gözümüz ilişmiş ve o işle ilgili olarak ertesi sabahı gözümüzün önüne getirmişsek birden bire bütün gece boyunca sıkılmış olduğumuzu farkediyoruz. Tabi böyle güzel geçmiş bir gecenin ardından bu tip olumsuz bir haletiruhiyeye nasıl girdiğimizi anlamakta zorlaniyoruz (Heidegger, 1995, s. 109).

İlk bakışta bu örnek, önceki sıkıntı tipine göre ne bizi reddeden, boşa çıkaran belli bir nesneden, ne de geçmek bilmeyen bir zaman diliminden

\footnotetext{
${ }^{14}$ Heidegger'in verdiği tren garı örneğini kendi dönemine uyarlayarak havaalanında uçak bekleme deneyimini gündeme getiren Svendsen, bu meseleyi şu şekilde açılkamayı uygun görmüştür: “... bir gecikme olduğunda, havaalanındaki bütüncül vaziyetim, her şey zaman çizelgesine uygun olarak gelişmiş olsa içinde olacağım vaziyetten farklılık arzeder ve vaziyetteki bu değişiklik farklı türden bir zaman deneyiminin ortaya çıkışına önayak olur. Sıkıntı gibi bir şey mümkündür, zira her şeyin kendi zamanı vardır. Eğer her şeyin kendi zamanı olmasa idi, sıkıntı da olmayacaktı. Demek ki sıkıntı, şeyin kendi zamanı ile bizim o şeyle karşılaşma zamanımız arasında bir uyuşmazlık olduğunda ortaya çıkar. $\mathrm{Bu}$ ise, sıkıntının özüne ilişkin olarak ortaya konulan soruya verilmiş deneme kabilinden bir cevap olarak düşünülebilir" (Svendsen, 2005, s. 119).
} 
söz etmeyi mümkün kılar görünmektedir. Burada gerçekleşme anı dört gözle beklenen ile bu bekleyişi kolaylaştıran oyalanma eylemleri arasında bir fark olduğunu iddia etmek mümkün değil gibi görünüyor. Kendisini amaç edindiğimiz ve kendisi ile oyalandığımız bir ve aynı şey: bir bütün olarak düzenlenen partinin kendisi. Parti ise, ilk örnekte kendisinden oyalanma talep etmiş olduğumuz tren garı ve kitap örneklerinin aksine bizi içine çekiyor, sırtımızdan zamanın ve sıkıntının yükünü alıyor, bizi kendi içinde eritip kendimizden geçiriyor. O halde problem ne? Heidegger görünüşteki açık benzemezliğe karşın bu örnekte de sıkıntının iki temel momentine, yani nesne tarafından boşa çıkarılma ve zaman tarafından arafta bırakılma temalarına başvurmakta ısrar eder.

Parti için kendimize zaman ayırmışızdır. Bu da orada geçireceğimiz zamanın tarafımızdan boşa geçen zaman olarak değerlendirilmeyeceğinin bir garantisi olarak anlaşılabilir. Buna karşın partide sıkılma, tam da bu anlamda, söz konusu garantiyi kendimize veremeyeceğimizin idrâk edilmesine bir örnek teşkil etmektedir. Hayata verdiği anlamı kendi varoluşsal olanakları ve yaptığı seçimler üzerinden gerçekleştirmeye, doyurmaya çalışan Dasein, örneğe konu olan sosyalleşme ortamının sahih benliğini hayata geçirmesinde yetersiz kaldığını görür. Bu anlamda katılıma konu olan partinin tamamı Dasein'ı boşa çıkarır, ona ait varoluşsal planların gerçekleşmesini sağlamaktan uzak kalır (Heidegger, 1995, s. 119).

Parti, devam ettiği müddetçe beklentiselliğin mümkün kılmakta olduğu gelecek kadar geçmiş kipini de dışarıda bırakacak biçimde Dasein'ı absorbe eder, oyalar. Parti zamanı âdeta uzayıp gitmiş bir şimdi haline gelir. Bu anlamda arafta bırakılma momenti, ilk örnekte olduğu gibi zamanın ayak sürümesi değil, durması olarak tezâhür eder. (Heidegger, 1995, s. 122). Uzamış ve durmakta olan şimdi, bizim bu parti için kendimize ayırmış olduğumuz zamandır. Heidegger bu noktada sözü edilmekte olan "şimdi" nin tam olarak onu deneyimlemekte olan Dasein olduğunu belirtir. ${ }^{15} \mathrm{Bu}$ hususu şöyle yorumlamak mümkündür: Geçmiş ve gelecek kiplerinin kapanması ile elastikiyet kazanan şimdi, bitmiş bir yaşamın modeli olabilecek bir tamamlanmışlı̆̆ı modeller. Tamamlanmışlık ise bitmiş bir kendiliği. Ve bu kendilik doğal olarak Dasein'1 memnun etmez,

15 İlk ve ikinci sıkıntı tipleri arasındaki temel fark, birincinin haletiruhiyeye dair nesnel tarafı açığa vurması iken, ikinci sıkıntı tipinin öznel yönü ön plana taşıması olarak görülebilir. Gerçekten de Gelangweiltwerden von etwas olarak tâbir edilen birinci sıkıntı, bir kitap ya da tren garının bizi sıkmasına gönderme yaparken; Sichlangweilen bei etwas şeklinde ifadeye büründürülen ikinci sıkıntı tipinde kendimizi sıkıntıya gark eden yine kendimizizdir (Biceaga, 2006, s. 145). 
onu sıkıntıya sürükler. ${ }^{16}$

Üçüncü sıkıntı tipinin örneği yoktur, zira Heidegger'in üçlü sacayağına oturan sıkıntı kavramsallaştırması, empirik olandan aşkınsal olana doğru hiyerarşik bir gidişat öngörmektedir. Üçüncü sıkıntı tipi, diğer iki sıkıntı tipinin aşkınsal/ontolojik koşulu olarak değerlendirilmeli; o ölçüde de her tür örnekleme ediminin hazırlayıcısı olarak görülmelidir.

Aslında meseleyi şu şekilde özetlemek de mümkündür: Şimdinin ötesine ve berisine, yani gelecek ve geçmişe sarkma olarak tasavvur edilmesi gereken Dasein, sıkılmak için yeri olan varlıktır. Şimdiye hapsolmamış olmak, zamanın üç kipinin birbirine uzanışı sonucu ortaya serilen açılığı işgal ediyor olmak, insan varlığının sıkılabilme kabiliyetine sahip olmasının yegâne anlamı gibi görünmektedir. Dasein'ın varoluşsal özü ihtimam [Sorge; care] ise ve ihtimam fenomeni onun zamansal özünü geçmiş, gelecek ve şimdinin karşılıklı olarak birbirlerine uzandıkları bir hareket [ecstasis] olarak betimlemeyi zorunlu kılıyorsa, durmuş zaman içinde "şimdi"ye kapanıp kalmış olmak dünyanın anlamını kaybetmesi ile mümkün olabilir, ki bu da sıkıntıdan başka bir şey değildir (Heidegger, 1995, s. 32).

Sıkıntı, Dasein'a ait hiçliği üretecek biçimde onu yarıp geçen zamanın zamanlamasından başka bir şey değildir. Dünyayla eşgüdümleniş (akortlanış) [attunement] olarak derin sıkıntı, kendine kapalı öznenin içinde kendi-dışını, ötekini üretecek olan zamanın hareketi olarak tanımlanabilir. Sıkıntı öznenin zaman tarafından zorunlu yarılışını imler ve bu yarılışın zorunluluğu ölçüsünde şeyleştirilmiş, "doğa" sına tutsak edilmiş, kendi içine kapalı öznenin ontolojik arkaplanında Dasein'ın bulunduğunu teslim etmek zarureti doğar. Derin sıkıntı olarak zuhur eden zamansallık Dasein'ı bilimlerin vaazetmiş oldukları zeminden koparır ve onu hiçlik, zeminsizlik üzerinde askıda bırakarak özgürlügüyle buluşturur. Sıkıntı, Dasein'ın özgürlüğünü sahip olunması muhtemel bir "doğa"dan bağımsızlaşmış-olma olarak anlamamızı sağlayacak yüzeysel olmayan bir paradigma sağlar.

Gidilen yerden geri dönememek; boşa çıkmak, boşta kalmak; arafta

16 “İlk sıkıntı tipinde, kullanıma hazır olan ama 'bize hiçbir şey sunmayan' şeyler tarafından, ikinci sıkıntı tipinde ise, herhangi bir şey tarafından "doldurulmayı" dahi talep etmeyi bırakmış kendi gündelikliğimiz sayesinde boşa çıkartılırız” (Boss, 2009, s. 95). Bu noktada Husserlci Erfüllung kavramsallaştırmasının ne dereceye kadar işe yarayacağı açık değildir, zira ortada gerçekleştirilecek bir beklenti, doldurulacak bir zaman yoktur. 
kalmak. Zaman Dasein'ın kendi kendisini etkileyebilmesi; kendi kendisine mâruz kalması olarak anlaşılmalıdır.

Sıkıntı durumunda Dasein kendisine yöneldiği nesneden âdeta itilmekte, onun tarafından boşa çıkartılmaktadır. Zira nesnenin içinde yer almakta olduğu alet edevat ağı ve söz konusu alet edevatı birbirine bağlamakta olan referans sistemi çöküntüye uğramıştır. Mevzubahis çöküntünün kaynağı ise, dünya olarak adlandırılmakta olan hedefler ve amaçlar sisteminin kendisi uğrunda birliğe geldiği nihai ereğin önemini kaybetmesi olarak açıklanabilir. Nihai ereğin tarihselliğe aşkın olan bir otorite tarafından değil de, yine kendisi tarafından konulmuş olduğunun idrâkine varan Dasein, kendisine zorunluluk atfetmeye meyyal olduğu hayatın anlamının kökeninde salt olumsallık yattığının da ayırdına varır. $\mathrm{Bu}$ ise, sahih Dasein'ın kendi varoluşunu edimsellik [actuality] yerine olanak [possibility] terimleri ile kavramaya başladığ 1 andır. Heidegger' in Dasein'a bir doğa atfetmek yerine onu olma-olanağ 1 [Seinkönnen] üzerinden ele almakta ısrarlı oluşunun nedeni, sözünü etmekte olduğumuz derin sıkıntı yaşantısının Dasein'a göstermekte olduğu kendi hakikatidir. Dasein bu noktada kendi zeminsizliğini ve hiçliğini kavrar; bir doğa tarafından sınırlanmış olmamak anlamına gelen özgürlüğünün gerçek anlamının ayırdına varır. Bu anlamda dünyaya karşı bir konumlanışı ifade eden varoluşsal endişe ve derin sıkıntı durumları, Dasein'a bir doğası olmadığını; bu doğanın olması gerektiği yerde hiçlik olduğunu gösterir. Dasein bir doğaya sahip değildir demek Dasein bir şey değildir demektir (İngilizce nothing, no-thing). Bir başka deyişle Dasein edimselleşmesi mümkün, potansiyel bir doğaya sahip olma anlaminda değil, böyle bir doğayı dışarıda bırakacak şekilde saf olanak olarak anlaşılması gereken bir kipte varolur. Dasein'ın özünün varoluşu olması, onun saf olarak düşünülmesi gereken olma-olanağı (Seinkönnen) olmasında yatar (Heidegger, 1995, s. 143).

\section{Sonuç: Çağımızın En Temel Sıkıntısı olarak Özsel Sıkıntı Eksikliği}

Sıkıntı üzerine yapmış olduğu bu çözümlemeler sonucunda Heidegger ontolojik zeminden politik zemine kayar görünen bir soru sorar: "Bugünün insanı kendisi için sıkıcı olmaya başlamış mıdır?" (Heidegger, 1995, s. 162). Burada filozof kendini metafiziğin derin sularından siyasî alanın görece somut dünyasına çekmeye çalışır gibidir.

Heidegger, tıpkı hocası Husserl gibi, çağı bir kriz çağı olarak görmektedir. 
Siyasikafa karışıklıkları, sanatın krizi, bilimin güçsüzlüğü, felsefenin temelsizliği vs. onun mevzubahis krizi betimlemek üzere başvurduğu terimlerden sadece bazılarıdır. Tüm bu alanlardan bir bitmişlik, sonuna gelmişlik, tükenmişlik kokusu yayılmaktadır. Bunun temel nedeni ise insanın kendisini mevcudiyet terimleri üzerinden anlamaya daha da yatkın hale gelişi ve bu sayede de kendinden olabildiği kadar uzaklaşmasıdır.

Dasein, kendi hakkında verdiği kararlar kaderi hâline gelen varlıktır. Bu anlamda Dasein'ın gerçek mânâda zamansal olduğunu, yani kendi boşluğunu kendi içinde taşıdığını söylemek icap eder. Sıkıntı ve endişe gibi temel varoluşsal modlar söz konusu boşluğu yukarıda tartışmış olduğumuz anlamda açığa vurmaktadırlar. Bunların üzerine ekilmiş olduğu toprağı sürmek ve çapalamak, yani kendini sıkıntının kollarına bırakmak, söz konusu sıkıntıdan imkanlar türetebilmenin tek yoludur ve bu da ancak ve ancak felsefeyle mümkün olabilir.

Buna karşın 21. yy. insanı olarak kendimizi içinde bulduğumuz vaziyet, sözünü etmekte olduğumuz sıkıntı durumuna karşı sergilenmekte olan müthiş bir kayıtsızlıktan ibaretmiş gibi görünmektedir:

Bir bütün olarak herhangi bir sıkıntının bugün eksik oluşu, belki de, en isabetli şekilde, bugün büyük ihtimalle kimsenin kendini Dasein'ında aşmıyor; ama bizlerin en iyi ihtimalle hayatın gizemi konusunda şikayetlenmeyi başarıyor oluşumuz olgusunda açığa çıkmaktadır (Heidegger, 1995, s. 165).

Kayıtsızlı̆ın şiddeti görünürdeki ihtimamın derecesi ile ters orantılıdır. Vurgulamakta olduğumuz ihtimam sıkıntı fenomenine tedavi edici, sağaltıcı bir tarzda yaklaşır ve bu sayede onu baskılayıp görünmez kılar. Bu tam da felsefenin sıkıntı fenomenini serbestleştirmeye çalışırken hedeflediği şeyin tersi yönde bir devinim üretmeye karşıllk gelir. Varoluşu özü olan varlık (yani, Dasein) önüne düşmekte olan gölgesini kovalayan varlıktır. Zamanın ruhu her şeyi kavrayıp tanılamak ister, ki bu da bazı hallerde gölgeyi ele geçirmeye çalışma gibi beyhude bir çabaya benzetilebilir. Dolayısıyla sıkıntıyı bir hastalık olarak tespit ve tedavi etmek gerekecektir. Bunun doğal sonucu ise onun teşhis edilme ihtimalini dahi ortadan kaldırmaktır.

Tedavi etmek ancak ve ancak tedavi edilecek olan tamlığında, bütünlüğünde ve normal işleyişinde zaten ve hâli hazırda tanınıyor ise 
mümkündür. $\mathrm{Bu}$ anlamda tedavi edilecek Dasein nesne haline getirilmeli, yani şeyleştirilip bütünlenmelidir. Bütünlüklü yapısından sapmış olanın noksanlığını giderecek olan sağaltım tekniği alıcısını bekleyen mal misali orada durmakta, talep edilmeyi beklemektedir. Doktorun muayenehanesi önünde bütünlenip tamir edilmeyi bekleyenlerin anlamadıkları şey şudur ki, onların varoluşları bir tamlık-eksiklik oyunu üzerine kurulu olan son derece dinamik bir süreçtir. Mesele bir şey-olmamaya tahammül etme meselesidir. Bu tahammülün Heidegger felsefesindeki karşılığ1 ise ketum ve kararlı bir duruşu yansıtmakta olan sahih varoluştur [authenticity]. Söz konusu sahih varoluş, sıkıntı üzerinden zamansallığının farkına varmış, bu sayede de kendi varlığını mevcudiyet terimleri üzerinden algılamayı bırakmış; bir başka deyişle, öz-aşkınlığının [self-transcendence] farkına varmış Dasein'ın sahih kendiliğine dönmesi olarak anlaşılmalıdır. Bu ise varlık ve varolanlar arasındaki ontolojik farka yeniden duyarlı hale gelme sürecini tekrar başlatmak; sıkıntı üzerinden felsefeyi bugün kaybetmiş olduğu eski prestijli konumuna iade etmek anlamına gelir (Withy, 2013, s.166). Lâkin durum odur ki, tahammülsüzlükten kaynaklı çağımızın hastalığı, sıkıntının bizi sıkıyor olmasından başka bir şey değildir (Heidegger, 1995, s. 163).

Peki tüm bu söylenenlerin politik olana açılma olanağı var mıdır? Bu soruyu şu şekilde de sormak mümkündür: Sıkıntının bizi sıkıyor olması bir "yabancılaşma" fenomeni olarak algılanabilir mi?

Geleneksel anlamda insanın özü, onun tamlığı ve bitmişliğine atıf yapar. Söz konusu tamlık, Dasein'ın varlık kipi açısından zamansallık ve sinırlılığı [finitude] bağlam dışıymış gibi gösterme yanılgısı üretir. [T11]. Bitmişlik ise, insanın dünyadaki ikâmeti için norm sağlayıcı bir kaynak olarak görülebilir. Bu, ademoğlunun gerek bireysel, gerekse de toplumsal yaşantısında kendi zamanötesi özüne sadık kalarak varolması gerektiğinin altını çizer, ki Batı metafizik geleneğini baştan sona biçimlendirdiğine kâni olduğu bu yaklaşım, Heidegger' in her daim eleştiri oklarını yöneltegeldiği yaklaşımdan başkası değildir. [T12] Kendi tamamlanmışlı̆̆ını değerlendirmeye katıp zaman ötesi özünü yaşama normu olarak hedefe koyan bir varoluş çizgisini tutturamayanların derhal tedavi edilmeleri gerekir. Diğer tarafta özü zamansallığı, bitmemişliği ve noksanlığından müteşekkil varlık olarak Dasein durmaktadır. Dasein'ın noksan olabilmesi, onun tamlığa ilişkin muğlak bir önkavrayışı olması sayesinde olanaklıdır. Fakat Dasein'ın trajedisi şudur ki, o sözü geçen tamlığın varoluş dışı bir kaynağı olmadığını, dolayısıyla kendi yapıtı 
olduğunu; bu anlamda da asla tam mânâsıyla âşina kılınabilir olmadığını sezer. Dasein yok olacağı ana kadar kim olduğunu söyleyememeye yazgılanmış olan varlık kipine verilen addır. Varoluşsal derin sıkıntı fenomeni, normun imlediği geleceğe ait bütünlenmişlik ve çevreleyen dünyanın kuşatıcı, transa geçirici etkisi arasında asılı kalma durumudur. Bu anlamda Dasein'ın kim-liği ya da temel sıkıntısı, kimliğe kavuşma imkanının olmamasıdır.

$\mathrm{Bu}$ acılı durum karşısında alınan tedbir, önerilen reçete yalnızca hastalığı katmerleyici bir işlev görür. Dasein'ın önüne ilâç niyetine bir takım "şey"ler konur, ve ondan da, sözü edilen bu "şey"lere yanıt verecek bir "şey" olduğunu itiraf etmesi beklenir. Teknobilimsel çağın tüm açıklamalarının nedensellik terimleri üzerine kurulu oluşunun alamet-i farikası, onun şeyleştirilmiş problemleri yine şey olan çözümler sayesinde bertaraf edebileceğine yönelik inancıdır. Öyle umuyorum ki, varoluşunu bir noksanlık (=özgürlük) olarak sırtlanmış bireyler olmaktansa reçeteler pazarının yer-tutucuları haline gelmiş olmamız yönündeki tespit, Nazizm lakırdısını tamamen dışarıda bırakacak biçimde, Heideggerci ontolojinin politik olandan pay almaya ne denli müsait olduğunun altını yeteri kadar çizmeye muvaffak olur.

Emrah Günok, Yüzüncü Yll Üniversitesi, Türkiye 


\section{Kaynakça}

Agamben, Giorgio. (2004). The Open: Man and Animal. Çev. Kevin Attell, Stanford University Press, California

Aristoteles. (2012). Fizik. Çev. Saffet Babür, Yapı Kredi Yayınları, İstanbul.

Biceaga, Victor. (2006). Temporality and Boredom. Continental Philosophy Review 39, ss. 135-153.

Boss, Matthew. (2009). Metaphysics and the Mood of Deep Boredom: Heidegger's Phenomenology of Mood. Essays on Boredom and Modernity: Critical Studies, Vol. 31 içinde. Yay. haz. Barbara Dalle Pezze ve Carlo Salzani, Rodopi, New York, ss. 85-107.

Gelven, Michael. (1989). A Commentary on Heidegger's 'Being and Time'. Northern Illinois University Press, Illinois.

Heidegger, Martin. (1962). Being and Time. Çev. John Macquarrie \& Edward Robinson. Blackwell Publishers Ltd., Oxford.

Heidegger, Martin. (1982). The Basic Problems of Phenomenology. Çev. Albert Hofstadter. Indiana University Press, Indianapolis.

Heidegger, Martin. (1995). The Fundamental Concepts of Metaphysics: World, Finitude, Solitude. Çev. William McNeill and Nicholas Walker. Indiana University Press, Indiana and Bloomington.

Heidegger, Martin. (2008). Varlık ve Zaman. Çev. Kaan H. Ökten. Agora Kitaplı̆̆ı, İstanbul.

Husserl, Edmund. (1970). Logical Investigations Volume II. Çev. J. N. Findlay. Routledge \& Kegan Paul, London.

Ratcliff, Matthew. (2013). Why Mood Matters. The Cambridge Companion to Heidegger's 'Being and Time'. Yay. haz. Mark A. Wrathall. Cambridge University Press, California, ss. 157-176.

Svendsen, Lars. (2005). A Philosophy of Boredom. Çev. John Irons. Reaktion Books, London.

Withy, Katherine. (2013). The Strategic Unity of Heidegger's 'The Fundamental Concepts of Metaphysics'. The Southern Journal of Philosophy. Vol. 51, Issue 2, ss. 161-78. 